\title{
Antisocial Behaviour: f Unidimensional or Multidimensional Construct?
}

\section{Conducta antisocial: ¿un constructo unidimensional o multidimensional? Conduta antissocial: um construto unidimensional ou multidimensional?}

\author{
Walberto Silva dos Santos* \\ Leonardo Carneiro Holanda* \\ Glysa de Oliveira Meneses* \\ Universidade Federal do Ceará \\ $\mathrm{M}^{\mathrm{a}}$. Angeles Luengo** \\ Jose Antonio Gomez-Fraguela** \\ Universidad de Santiago de Compostela
}

Doi: http://dx.doi.org/10.12804/revistas.urosario.edu.co/apl/a.5105

\section{Abstract}

This study aimed at evaluating the internal consistency of the Antisocial Behavior Questionnaire and analyze its factor structure. Specifically, it sought to evaluate the suitability of one-factor and multifactorial models, and to verify the extent to which scores of antisocial behavior vary according to gender. We counted with two different samples of school adolescents. They answered, among other measures, the Antisocial Behavior Questionnaire and demographic questions. The results indicated that the multidimensional model composed of five independent factors was more suitable than the one-factor model as well as the model with five factors of first order and a higher order factor. The male participants had higher scores on aggression, theft, conduct against the rules and vandalism. No significant differences were found for problems with drug abuse. We conclude, therefore, that the antisocial behavior is adequately represented by a multidimensional structure comprising acts of different types and gravities, and that these are more likely in males than females.

Keywords: Antisocial behavior, dimensionality, factorial structure, gender differences.

\section{Resumen}

Este estudio tuvo como objetivo evaluar la consistencia interna del Cuestionario de Comportamientos Antisociales y analizar su estructura factorial. Específicamente,

* Universidade Federal do Ceará.

** Universidad de Santiago de Compostela.

To quote this article: dos Santos, W., Holanda, L., Meneses, G., Luengo, M. A., \&, Gómez-Fraguela, J. A. (2019). Antisocial behaviour: a unidimensional or multidimensional construct? Avances en Psicología Latinoamericana, 37(1), 13-27. Doi: http:// dx.doi.org/10.12804/revistas.urosario.edu.co/apl/a.5105 
se buscó comprobar la adecuación de un modelo unifactorial y dos multifactoriales, además de verificar en qué medida las puntuaciones de los comportamientos antisociales varían en función del género de los participantes. Para su realización se contó con dos muestras distintas de adolescentes escolarizados. Estos respondieron, entre otras medidas, al Cuestionario de Comportamientos Antisociales y a algunas preguntas demográficas. Los resultados indicaron que el modelo multidimensional compuesto por cinco factores independientes fue más adecuado que el modelo unifactorial y que el modelo con cinco factores de primer orden y un factor de orden superior. Los participantes de sexo masculino presentaron una mayor puntuación en los factores agresión, robo, conducta contra las normas y vandalismo, no existiendo diferencias significativas para problemas con abuso de drogas. Se concluyó, por lo tanto, que los comportamientos antisociales son adecuadamente representados por una estructura multidimensional compuesta por actos de diferentes tipos y gravedad, y que estos son más probables en individuos del sexo masculino que del femenino.

Palabras clave: conducta antisocial, dimensionalidad, estructura factorial, diferencia de género.

\section{Resumo}

Este estudo teve como objetivo avaliar a consistência interna do Questionário de Comportamentos Antissociais e analisar a sua estrutura fatorial. Especificamente, buscou-se comprovar a adequação de um modelo unifatorial e dois multifatoriais, além de verificar em que medida as pontuações dos comportamentos antissociais variam em função do gênero dos participantes. Para a sua realização contou-se com duas amostras distintas de adolescentes escolarizados. Eles responderam, entre outras medidas, ao Questionário de Comportamentos Antissociais e a algumas perguntas demográficas. Os resultados indicaram que o modelo multidimensional composto por cinco de primeira ordem e um fator de ordem superior. Os participantes de sexo masculino apresentaram uma maior pontuação nos fatores agressão, roubo, conduta contra as normas e vandalismo, não existindo diferenças significativas para problemas com abuso de drogas. Concluiu-se, portanto, que os comportamentos antissociais são adequadamente representados por uma estrutura multidimensional composta por atos de diferentes tipos e gravidade, e que estes são mais prováveis em indivíduos do sexo masculino que do feminino.

Palavras-chave: conduta antissocial, dimensionalidade, estrutura fatorial, diferença de gênero.

\section{Introduction}

Antisocial behaviour by young people has not only raised wide interest in the social sciences but it has also prompted a conceptual challenge. Studies do have used different concepts, such as juvenile delinquency (Pridemore, 2002; Ryan, Williams \& Courtney, 2013), antisocial behaviour (van Lier, Vitaro, Wanner, Vuijk \& Crijnen, 2005; Curtis, 2016), antisocial personality disorder (Holmes, Slaughter \& Kashani, 2001; Ogloff, Campbell \& Shepherd, 2016), conduct problems (Jessor \& Jessor, 1977; White et al., 2016) and disruptive behaviour (American Psychiatric Association, 2013; Loeber, Burke, Lahey, Winters \& Zera, 2000, Bubenzer-Busch et al., 2016; Baldry, Farrington \& Sorrentino, 2016) to access antisocial behaviour. Although these constructs may appear to be synonymous, most research in the area was carried out from a variety of conceptual perspectives and different approaches where the definition and the identification of the target participants were based on different criteria and methodological procedures, which makes the integration of the results problematic and suggests that the constructs are different (Luengo, Otero-López, Romero, Gómez-Fraguela \& Tavares-Filho, 1999; Rhee \& Waldman, 2002).

A large number of researchers have traditionally focused on categorical criteria to identify their participants. At least two perspectives should be highlighted here: Firstly, the juridical, in which 
the "delinquent" label can be applied only to those people who have been considered guilty by a judge after committing a crime; and secondly, classic psychiatry, in which diagnostic categories, such as dissocial disorder or antisocial personality disorder, apply to patients with a series of symptoms specified in classification system manuals, such as the Diagnostic and Statistical Manual of Mental Disorders (DSM-V; American Psychiatric Association, 2013) or the International Classification of Diseases (ICD-10; World Health Organization, 1992).

The majority of studies which have been carried out in accordance with these criteria have been considered very restrictive and of little use in the explanation of the etiology of antisocial behaviour. They tend to focus on a limited number of cases where deviant conduct happens more frequently and with greater seriousness. Many of them do not take into account those individuals who have committed criminal acts and who have not been detected by the control systems; it has been estimated that more than half of the individuals who commit crimes remain undetected by the judicial system (Dickson, Emerson \& Hatton, 2005; Latimer, Kleinknecht, Hung \& Gabor, 2003). This situation is not different in the mental health field, where the number of diagnosed cases is relatively small, especially when compared to the population that fulfils the established criteria for diagnosis of certain diseases.

It has been observed that individuals identified as "delinquents" by penal and health systems do not constitute a representative sample of the group of people who could be identified as such. Usually, during the identification process, implicit biases can be observed both in the judicial ('dark number' bias on judicial performance) and the health (access and identification of the population that meets the diagnostic criteria) systems. These biases produce a large number of cases that despite involving similar types of behaviour are less likely to be identified as delinquent or diagnosed as antisocial personality disorders.
While attempting to overcome these problems in the 1950 s, studies began to approach antisocial behaviour from a dimensional perspective, employing self-reports as the main method of research (Thornberry \& Krohn, 2000). During this period, one of the most significant advances was the inclusion of the label "antisocial" in behaviour which is harmful to society although it is not illegal (Jessor \& Jessor, 1977). This inclusion had an important effect at a theoretical level because this type of antisocial behaviour presents similar antecedents and manifestations to that which represents serious transgressions of the law. At the same time, it has been suggested that during the individual evolutive course antisocial behaviour which is harmful but not illegal constitutes a predictor of the development of more severe deviant behaviour (Loeber \& Dishion, 1983; Paquette, 2015). What we consider to be of relevance here is that the phenomenon is conceived as a dimensional continuum and not as a categorical all-or-nothing one. This enables one to study not only children and adolescents who begin to commit acts of limited seriousness, and do so not very frequently, but also those who have a long history of acts of considerable seriousness which are committed frequently. This means that the biases arising from the conduct of legal agents (the black list, biases of judicial conduct, etc.), as well as the difficulties the public health authorities may have in gaining access to, diagnosing and identifying the population which fulfills the diagnostic criteria for these types of disorders, can be overcome.

Moreover, the effort previously applied at the refinement of diagnostic criteria can know be exerted to the understanding of the relationship between certain variables and the occurrence of antisocial behavior throughout the lifespan. Due to the complexity of this construct, several risk factors for the development of antisocial behavior have been investigated (Hemphill, Heerde, Herrenkohl \& Farrington, 2015). Researchers have pointed out that parental practices in association 
with groups of deviant peers play an important role on juvenile antisocial behavior. Regarding parental practices, low levels of parental monitoring and support associated with the occurrence of family conflicts seem to be directly related to adolescent behavior problems (Cutrín, Gomez-Fraguela, Maneiro \& Sobral, 2017; Nardi, Hauck Filho \& Dell'Aglio, 2016). Over time, young people become more influenced by peer groups; it is observed that adolescents spend more time in the company of others of the same age, and that they engage in antisocial behavior more often when they are in a group (Knoll, Magis-Weinberg, Speekenbrink \& Blakemore, 2015; Morgado \& da Luz Vale-Dias, 2016). In this way, difficulties related to the family environment can increase adolescents' vulnerability to peer influence and, thus, increase their chances of engaging in risk behaviors (Sehn, Porta, Santos \& Dias, 2016).

The literature also emphasizes that personality and neighborhood-related could be preponderant aspects for the development of antisocial behavior (Cutrín, Gómez-Fraguela, Maneiro, Sobral, \& Luengo, M.A., 2016; Maneiro, Gómez-Fraguela, Cutrín, \& Romero, 2017). As for the personality traits, the association between conduct problems and a callous-unemotional personality style, characterized by lack of remorse and empathy, stands out; in addition, low impulse control is also associated with delinquency and substance use (Klinzell, Fanti, Colins, Frogner, Andershed \& Andershed, 2016). Regarding neighborhood issues, literature has pointed to elements ranging from social class or family income to other factors such as violence, delinquency or lack of resources that may be present in the social environment (Cutrín et al., 2016).

Despite theoretical and methodological advances observed in the last few years, there is no consensus on the nature and dimensionality of antisocial behaviour. Jessor and colleagues consider this construct to be a syndrome of problem behaviour defined by one factor that groups a set of deviant acts - e.g., alcohol and illegal drugs use, misdemeanors, premature sexual intercourse, etc. (Jessor, Donovan \& Costa, 1991; Jessor \& Jessor, 1977) —. This viewpoint is the polar opposite of the prosocial factor composed of activities related to involvement with conventional agents of socialization (family, school and other traditional organizations). In addition to Jessor, other researchers have expressed their agreement with this concept (Farrell, Kung, White \& Valois, 2000; Farrington, 1995; Sherman, Chassin, Sherman, Presson \& Macy, 2016).

An alternative point of view, with different typologies, suggests that antisocial behaviour presents a multidimensional nature. Loeber and colleagues (Burke, Loeber \& Birmaher, 2002; Loeber \& Stouthamer-Loeber, 1998; Thornberry, Huizinga \& Loeber, 2004) propose the existence of three evolution patterns in problematic conducts in infancy and adolescence: An "overt pattern," characterized by the presence of aggressive behaviour; a "covert pattern," related to acts against property; and a pattern of conflict with authorities, characterized in infancy by defiant behaviour followed by conducts that avoid adult control (e.g., running away from home or squandering).

Studies also make a distinction between socialized and undersocialized aggression (Quay, 1987), criminal and antisocial behaviour (Seisdedos, 1988; Formiga, Duarte, Neves, Machado \& Machado, 2015), destructive covert behaviour, non-destructive behaviour, and overt behaviour (Olzcak, Parcell \& Stott, 1983; Storvoll, Wichstrom, Kolstad \& Pape, 2002; Styles, 2015). Other researchers propose a multidimensional model where the factor structure that presents the best fit to antisocial behaviour is constituted by various first-order factors grouped around a higher order factor (Ennett et al., 2015; Farrell et al., 2000). The Antisocial Behaviour Questionnaire, which was developed by the authors in line with this latter multidimensional approach, is a self-report measure directed at adolescents in which five specific 
dimensions are evaluated: Aggression, vandalism, theft, anti-normative behaviour and drug-related problems.

Self-reports are acknowledged as an efficacious and valid technique in delinquency studies (Thornberry \& Krohn, 2000; Curcio, Mak \& Knott, 2015) and they offer considerable reliability which includes temporal stability (test-retest reliability). According to Thornberry and Krohn, in terms of validity, self-report responses are in no way different from any other kind of measure in the social sciences. They suggest that despite having problems, which are inherent to other types of instruments, self-reports constitute a simple, viable and low-cost technique for the development of research with large samples and longitudinal studies when the sensitivity of the object of study is being considered.

Since its preparation, it has been used in several studies which have demonstrated its adequacy in the measurement of antisocial behaviour $(\mathrm{Ga}-$ raigordobil \& Oñederra, 2015; Luengo, Carrillo, Otero-López \& Romero, 1994; Luengo et al., 1999; Maneiro et al., 2017; Mirón, Otero-López \& Luengo, 1988; Romero, Gómez-Fraguela, Luengo \& Sobral, 2003; Romero, Luengo, Sobral \& Marzoa, 2001). The questionnaire was subsequently revised (Luengo et al., 1999) using samples of 12-18 years-old adolescents selected from the general population and from remand homes in two different cultural contexts (Brazil and Spain). As a result of this study, 12 of the 82 original items were removed because they did not make a significant distinction between offenders and non-offenders. The drug scale was also reduced: Of the 21 items concerned with drug consumption and its consequences in the original version, the items concerned with consumption were removed so that there were 11 items left on the scale. As a result, the revised version of the Antisocial Behaviour Questionnaire was made up of 60 items.

This study proposed the following: Firstly, drawing up a reduced version of the CCA to use with schoolchildren; secondly, analysing its internal consistency and deciding whether a unifactorial model, with all the distinctive behaviour grouped in one factor, or a multidimensional model, constituted by five first-order factors grouped around one higher order factor, would be the factor structure that best fitted the data in samples of adolescents. In addition, the extent to which gender differences affect the scores is also analyzed.

\section{Method}

\section{Participants}

Two studies made up of two independent samples were conducted. All the participants were adolescents from Galícia, a region in the north west of Spain. Sample 1 was composed of 290 adolescents, $30.1 \%$ were first-year students from vocational training schools while the other participants were from high schools. They were aged between 14 and 18, with a mean age of 16 years $(S D=1.1)$, females made up 53.4\%. Sample 2 was composed of 474 students from high schools and vocational training schools. They were aged between 14 and $18(M=15.6 ; S D=1.5)$, with the percentage of males $(52.5 \%)$ being slightly larger than that of the females.

\section{Instruments}

A 64-item version of the Antisocial Behaviour Questionnaire (ABQ-R, Luengo et al. 1999) was used for both studies. Participants were asked how often they had performed a series of antisocial acts during the preceding 12 months. The items were grouped conceptually in five dimensions: Aggressive acts against other people (aggression, 15 items); aggressive acts against objects (vandalism); theft of different levels of seriousness; conducts against established norms (10 items); and drug-related behaviour. The answers were given in a 4-point Likert scale: Never (0); A few 
times ( 1 to 5 times); Many times (6 to 10 times); and Frequently (more than 10 times). The internal consistency level obtained from the Spanish samples is satisfactory, with Cronbach's Alpha indexes varying from .82 for vandalism (10 items) to .95 for theft (16 items). The total set of items presented an internal consistency of .98 (Luengo et al. 1999).

\section{Procedure}

The studies used a questionnaire packet that included the ABQ-R. The questionnaires were answered in a classroom context during school time in the presence of research group members who had previously obtained consent from the students' parents. Before presenting the questionnaires, the research assistants presented the instructions, emphasizing that participation was voluntary, confidential and anonymous. All ethical procedures were followed.

\section{Statistical Analyses}

Sample 1. Using the data from the first sample, an analysis of items was carried out in order to both make the selection of the items that best represented the ABQ- $\mathrm{R}$ factors and to be able to obtain reduced scales for each one of the five dimensions of antisocial behaviour. The selection criteria for the items was the highest item-total corrected correlations (Henrysson, 1963). Four items in each dimension were retained for running a confirmatory factor analysis. This number of indicators (observed variables) followed the recommendation for the adequate identification of a construct (latent variable, Hau \& Marsh, 2004).

Multiple confirmatory factor analyses (CFA) were conducted with the selected items using the data from Sample 2. The main objective of these analyses was to check the factorial structure that best fits the data. The analyses were run using the software AMOS 6 with the covariance matrix, as well as this, the maximum likelihood method (ML) was employed. The global fit of the models was analyzed using the Chi-square, which provides significance tests of the degree to which the proposed model fits the data, with high values indicating a bad fit. The chi-square difference and its respective degrees of freedom $\left[\Delta \chi^{2}(\mathrm{DF})\right]$ has been used as a useful criterion to compare the fit to alternative models (Byrne, 2001; Garson, 2003). Additional fit indexes were also used. Firstly, the Goodnessof-fit Index (GFI), which evaluates the explained variability of the model with values which may vary between zero (bad fit) and 1.0 (perfect fit), while values higher than .90 were considered acceptable. Secondly, the Root-mean-square Error of Approximation (RMSEA), where values near zero $(0)$ indicate a better fit. For this index, values smaller than .08 are indicated. Finally, the Root Mean Square Residual (RMR), an indicator that takes the residuals into consideration, with smaller values close to .05 indicating the adequacy of the model (Byrne, 2001; Tabachnick \& Fidell, 2007).

Multivariate Analyses of Variance (MANOVA) were used to compare the scores of antisocial behaviour according to gender after the appropriate model had been identified.

\section{Results}

A version composed of 20 items was made by using a data reduction process. Item correlations with the corrected total score for each theoretical factor are presented in Table 1. According to these findings, four items from the original scale formed the Aggression factor and presented high homogeneity indexes (from .60 to .69), reaching .72 on the Cronbach's Alpha index. The scales related to Vandalism, Theft and Drugs presented homogeneity indexes varying between .47 and .73. In these dimensions, the internal consistency indexes (Cronbach's alpha) also presented acceptable values: .81 for Theft .77 for Vandalism; and .70 for Drugs. The item-total correlation of 
the Antinormative Conduct scale varied between .37 and .55 , presenting a Cronbach's alpha of .61 with four items. As these factors are directly and significantly correlated $(p<.01)$, the internal consistency index of the total scale was also calculated $(\mathrm{a}=.91)$.

Table 1.

Summary of Construct Items Used in the Structural Equation Models

\begin{tabular}{rr}
\hline Item Description & CITC* \\
\hline Factor I - Aggression $(\alpha=72)$ &
\end{tabular}

03. Beating up someone in a fight.

29. Fighting with another person with mutual blows.

24. Using any type of weapon in a fight.

21. Attacking a police that tries to stop another person.

Factor II - Vandalism $(\alpha=.77)$

14. Breaking a window. .60

01. Breaking empty crystals of house.

02. Setting fire to something: a wastebasket, a table, a car.

5. Hitting, breaching or scratching parked cars or motorbikes.

Factor III - Theft $(\alpha=.81)$

26. Taking the stranger bicycle and to keep it. .73

25 . To enter an other people's house without permission with intention to rob.

35. Gliding to enter a house, floor, etc. in order to rob and to carry out it.

41. Stealing materials to people who are working.

Factor IV - Antinormative conducts $(\alpha=.61)$

18. Escaping of the police.

49. Spending the night out of home, without permission.

15. Running away from home.

43. Drawing for a ilegal job.

Factor V - Drug-related $(\alpha=.70)$

63. Taking part in illegal acts to obtain drug. .66

\begin{tabular}{lc}
\hline \multicolumn{1}{c}{ Item Description } & CITC* \\
\hline 09. Taking drug with friends in group. & .62 \\
$\begin{array}{l}\text { 56. Taking a "flash" or a faint as a result of tak- } \\
\text { ing drug. }\end{array}$ & .54 \\
42. Being capable to find the drug seller easily. & .47 \\
\hline Note: * Corrected Item-total Correlation
\end{tabular}

After the item selection, the next step was to run confirmatory factor analyses to examine which factor structure presented the best fit to the data. Two specific models were tested to this end: Model 1 grouped the 20 items from precedent analyses in one single antisocial behaviour factor; Model 2 distributed these items into five first-order factors (aggression, vandalism, antinormative conducts, theft, and drugs) under one higher-order factor. Fit indexes for each of these models can be found in Table 2.

Table 2.

Comparison of the Factor Models of the Antisocial Behaviour Questionnaire

\begin{tabular}{|c|c|c|c|c|c|c|c|}
\hline $\begin{array}{l}\text { Mo- } \\
\text { dels }\end{array}$ & $\chi^{2}$ & d.f. & $\chi^{2 / \text { d.f }}$ & GFI & RMR & $\begin{array}{l}\text { RMSEA } \\
(\mathrm{IC} 90 \%)\end{array}$ & $\Delta \chi^{2}$ \\
\hline $\begin{array}{l}\text { Mo- } \\
\text { del } \\
1\end{array}$ & 627.61 & 170 & 3.69 & .879 & .014 & $\begin{array}{c}.075 \\
(.069- \\
.082)\end{array}$ & \multirow{2}{*}{$135.51^{*}$} \\
\hline $\begin{array}{l}\text { Mo- } \\
\text { del } \\
2\end{array}$ & 492.10 & 165 & 2.98 & .905 & .011 & $\begin{array}{c}.065 \\
(.058- \\
.071)\end{array}$ & \\
\hline
\end{tabular}

The model that presented a better fit was Model 2 because it corroborated the existence of five specific first-order factors and one second-order factor, entitled antisocial behaviour, and presented adequate goodness of fit indexes $\chi^{2}(165)$ $=492.10, p<.001, \chi^{2} / d f=2.98, G F I=.905$, $R M R=.011$ e $R M S E A=.065$ (Confidence interval $90 \%=.058-.071)$. This model, when compared to model 1 , is more appropriate $\left[\Delta \chi^{2}(5)=135.51\right.$, $p<.001]$. Figure 1 presents the estimated parameters for this model. 


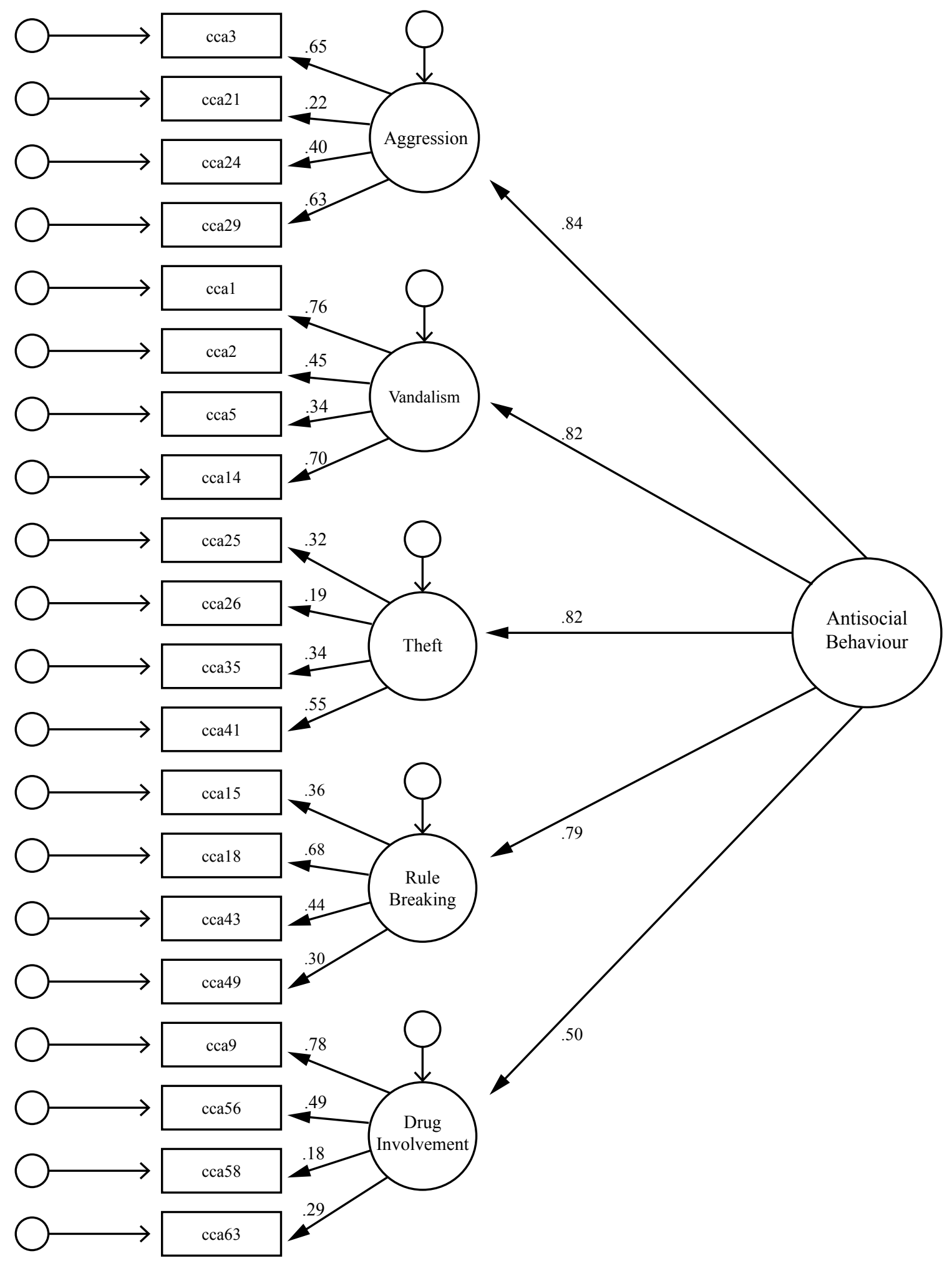

Figure 1. Multifactorial Structure of the Antisocial Behaviour Questionnaire 
These results show that the measurement of antisocial behaviour is adequately represented by five factors with all saturations statistically significant $(t>1.96, p<.05)$. Finally, as previous studies report differences between antisocial behaviour scores according to gender (e.g. Latimer, Stone, Voight, Winters \& August, 2002; Tuvblad, Eley \& Lichtenstein, 2005), this hypothesis was also tested.

Multiple analyses of variance were run, comparing the mean scores of men and women from sample 2 in each one of the antisocial behaviour dimensions. As table 3 indicates, this variable presented an important effect on antisocial behaviour scores: Except for the behavioral dimension related to drugs, one-tailed tests (F) suggested that men tend to exhibit more antisocial behaviour than women.

Table 3.

Antisocial Behaviour Factor Differences According to Gender

\begin{tabular}{lcrrrc}
\hline \multirow{2}{*}{$\begin{array}{l}\text { Antisocial } \\
\text { Behaviour }\end{array}$} & \multicolumn{2}{c}{ Boys } & \multicolumn{3}{c}{ Girls } \\
\cline { 2 - 6 } & $\mathrm{M}$ & $\mathrm{SD}$ & $\mathrm{M}$ & $\mathrm{SD}$ & $\mathrm{F}$ \\
\hline General Factor & .24 & .20 & .10 & .14 & $74.77^{*}$ \\
Aggression & .36 & .33 & .17 & .24 & $52.79^{*}$ \\
Vandalism & .43 & .41 & .12 & .22 & $106.27^{*}$ \\
Theft & .09 & .16 & .02 & .08 & $29.96^{*}$ \\
Antinormative & .22 & .33 & .13 & .24 & $13.50^{*}$ \\
conducts & & & & & \\
Drug-related & .11 & .23 & .09 & .22 & 1.50 \\
\hline
\end{tabular}

Note: $* p<.001$

\section{Discussion}

The main objective of this study was to evaluate the factor structure of the Antisocial Behaviour Questionnaire (ABQ-R, Luengo et al., 1999) and to verify its internal consistency in samples of adolescent school children. The influence of gender on antisocial behaviour scores was also analysed.
The findings suggest these objectives were appropriately attained.

Except for the Antinormative Conducts factor, all dimensions presented acceptable Cronbach's Alpha ( $\geq .70$; Nunnally \& Bernstein, 1994). However, it is important to note that alpha indexes close or equal to .60 can also be considered acceptable, especially when the factors are constituted by a reduced number of items and the scale is proposed for research purposes (Clark \& Watson, 1995; Garson, 2007).

In addition to presenting information related to the accuracy of the ABQ-R, this study also empirically analyzed two different models of antisocial behaviour. These analyses have suggested that the construct is best represented by a multidimensional structure, which corroborates previous research. Thornberry and Krohn (2000), for example, state that delinquency comprises an extensive array of behaviour that might extend from truancy to such acts as grave aggression and homicide. Empirical evidence suggests this construct does not present a unifactorial structure. Recent publications refer to antisocial behaviour as a variable that groups distinct types of acts (Carter, Gray, Baillargeon \& Wakschlag, 2013; Farrington, 2005; Russell \& Odgers, 2016; van Lier, Wanner \& Vitaro, 2007; Youngs, Canter \& Cooper, 2004), and these findings were corroborated here.

Analyzing delinquency through a multidimensional model enables the comparison of specific types of antisocial behaviour and helps in the analysis of variables related separately to each one of them. In practical terms, this proposal is relevant for research and intervention on individuals in schools from the general population, as well as on institutionalized delinquents because it enables a specific analysis of each type of antisocial conduct, enhancing the possibilities of understanding each type of behavior, along with its backgrounds and particularities.

In relation to gender, the results do not contradict previous studies (see Burton \& Marshall, 
2005; Youngs et al., 2004). Antisocial behaviour tends to be more frequent in males than in females (Eme, 2015), except when it is related to drug use (Kennedy, Epstein, Phillips \& Preston, 2013). Although there is an indication that psychoactive substances are used more by men (Svensson, 2003), other studies suggest this difference does not exist. Pelissier and Jones (2005), reviewing studies published in the U.S. and Canada between 1985 and 2003, observed that in the majority of studies, the global frequency or gravity of drug use is not different between men and women.

Gender differences can be found when the analyses are related to aspects of the substance type, to initial consumption and to other related variables. However, findings published in many of these studies are still not consensual, especially when the different contexts in which they were developed becomes clear. A research with Austrian adolescents (Rumpold et al., 2006) has shown that 16-year-old women smoke more cigarettes than men of the same age; nevertheless, when the consumption of other substances (e.g., marijuana) is compared, these groups do not differentiate even when different age groups are considered. This similarity of scores presented by male and female in the drug-related problems dimension of the ABQ- $R$ would suggest that drug consumption is not an exclusively masculine phenomenon (Mullis, Cornille, Mullis \& Huber, 2004). Since an extensive literature point out that antisocial behaviour is more frequently associated with males, for almost every type delinquent and antisocial behaviour other than those concerning drugs, our results reinforce the necessity of a better understanding of the risk factors that follow the female gender concerning drug related behaviour.

Although our findings are similar to those of other researchers in the literature, it is important to emphasize that this study may also present potential limitations. This is particularly so with regard to the number of participants who cannot be considered representative of the population, and this obviously restricts the possibility of generalization. Nevertheless, this was neither the final aim of the study nor does it invalidate the results. For precision and dimensionality analyses, the presented samples $(n>200)$ are considered adequate (Nunnally \& Bernstein, 1994).

Finally, there is clearly a need for future studies which would concentrate both on certain particular aspects of the nature and dimensionality of antisocial behaviour and on the adequacy of the selected items for model composition. Thus, testing the convergent validity and checking the reliability of this reduced version of the $\mathrm{ABQ}$ would be important while testing other larger samples which include adolescents from other cultures independent of the Spanish one would also be of interest. Likewise, upcoming research should investigate the relevancy of $\mathrm{ABQ}$ in institutionalized populations.

\section{References}

American Psychiatric Association. (2013). Diagnostic and statistical manual of mental disorders. Arlington, VA: American Psychiatric Publishing. Baldry, A. C., Farrington, D. P., \& Sorrentino, A. (2016). Cyberbullying in youth: a pattern of disruptive behaviour. Psicología Educativa, 22(1), 19-26. Doi: https://doi.org/10.1016/j. pse.2016.02.001

Bubenzer-Busch, S., Herpertz-Dahlmann, B., Kuzmanovic, B., Gaber, T. J., Helmbold, K., Ullisch, M. G., ... Zepf, F. D. (2016). Neural correlates of reactive aggression in children with attention-deficit/hyperactivity disorder and comorbid disruptive behaviour disorders. Acta Psychiatrica Scandinavica, 133(4), 310-323. Doi: doi: 10.1111/acps. 12475

Burke, J.D., Loeber, R., \& Birmaher, B. (2002). Oppositional defiant and conduct disorder: a review of the past 10 years, part II. Journal of the American Academy of Child and Adolescent Psychiatry, 41(11), 1275-1293. Doi: http://dx. doi.org/10.1097/00004583-200211000-00009 
Burton, J. M., \& Marshall, L. A. (2005). Protective factors for youth considered at risk of criminal behaviour: does participation in extracurricular activities help? Criminal Behaviour and Mental Health, 15(1), 46-64. Doi: http://dx.doi. org/10.1002/cbm.36

Byrne, B. M. (2001). Structural equation modeling: Perspectives on the present and the future. International Journal of Testing, 1(3-4), 327334. Doi: https://doi.org/10.1080/15305058. 2001.9669479

Carter, A. S., Gray, S. A., Baillargeon, R. H., \& Wakschlag, L. S. (2013). A multidimensional approach to disruptive behaviors: Informing life span research from an early childhood perspective. In Tolan, P. H. \& Leventhal, B. L. (Eds.), Disruptive Behavior Disorders (pp. 103-135). New York: Springer. Doi: http://dx. doi.org/10.1007/978-1-4614-7557-6_5

Clark, L. A., \& Watson, D. (1995). Constructing validity: basic issues in objective scale development. Psychological Assessment, 7(3), 309-319. Doi: http://dx.doi.org/10.1037/10403590.7.3.309

Curcio, A. L., Mak, A. S., \& Knott, V. E. (2015). The Australian Self-report Delinquency Scale: A revision. Australian Journal of Psychology, 67(3), 166-177. Doi: http://dx.doi.org/10.1111/ ajpy. 12075

Curtis, C. (2016). Anti-Social Behaviour: A multi-national perspective of the everyday to the extreme. London: SAGE.

Cutrín, O., Gómez-Fraguela, J.A., Maneiro, L., Sobral, J. \& Luengo, M.A. (2016). Psychopathic traits mediate the effects of neighbourhood risk on juvenile antisocial behaviour. Psicothema, 28 (4),428-434. doi:10.7334/psicothema2016.55

Cutrín, O., Gómez-Fraguela, J. A., Maneiro, L., \& Sobral, J. (2017). Effects of parenting practices through deviant peers on nonviolent and violent antisocial behaviours in middle-and late-adolescence. The European Journal of Psychology
Applied to Legal Context, 9(2), 75-82. Doi: https://doi.org/10.1016/j.ejpal.2017.02.001

Dickson, K., Emerson, E., \& Hatton, C. (2005). Self-reported antisocial behaviour: Prevalence and risk factors amongst adolescents with and without intellectual disability. Journal of Intellectual Disability Research, 49(11), 820826. Doi: http://dx.doi.org/10.1111/j.13652788.2005.00727.x

Eme, R. (2015). Sex difference in attention-deficit/ hyperactivity disorder contributes to the sex difference in crime and antisocial behavior. Violence and Gender, 2(2), 101-106. Doi: http:// dx.doi.org/10.1089/vio.2014.0025

Ennett, S. T., Jackson, C., Cole, V. T., Haws, S., Foshee, V. A., Reyes, H. L. M., Burns, A. R., Cox, M. J., \& Cai, L. (2015). A Multidimensional Model of Mothers' Perceptions of Parent Alcohol Socialization and Adolescent Alcohol Misuse. Psychology of Addictive Behaviors, 30(1), 1828. Doi: http://dx.doi.org/10.1037/adb0000119 Farrell, A. D., Kung, E. M., White, K. S., \& Valois, R. F. (2000). The structure of self-reported aggression, drug use, and delinquent behaviors during early adolescence. Journal of Clinical Child Psychology, 29(2), 282-292. Doi: http:// dx.doi.org/10.1207/S15374424jccp2902_13

Farrington, D. P. (1995). The challenge of teenage antisocial behavior. In M. Rutter (Ed.), Psychosocial disturbances in young people: Challenges for prevention (pp. 83-130). New York, NY: Cambridge University Press.

Farrington, D. P. (2005). Childhood origins of antisocial behavior. Clinical Psychology and Psychotherapy, 12(3), 177-190. Doi: http://dx.doi. org/10.1002/cpp.448

Formiga, N., Duarte, V., Neves, S., Machado, M., \& Machado, F. (2015). Scale of Antisocial and Criminal Conducts: factorial structure of the Portuguese version. Psicologia: Reflexão e Crítica, 28(4), 718-727. Doi: http://dx.doi. org/10.1590/1678-7153.201528409 
Garaigordobil, M., \& Oñederra, J. A. (2015). Inteligencia emocional en las víctimas de acoso escolar y en los agresores. European Journal of Education and Psychology, 3(2), 243-256.

Garson, G. D. (2003). PA 765 Statnotes: an online textbook. Retrieved from: http://www2.chass. ncsu.edu/garson/pa765/statnote.htm.

Garson, G. D. (2007). Scales and standard measures. Retrieved from: http://www2.chass.ncsu.edu/ garson/pa765/standard.htm.

Hau, K., \& Marsh, H. W. (2004). The use of item parcels in structural equation modeling: Non-normal data small sample sizes. British of Mathematical Statistical Psychology, 57(2), 327-351. Doi: http://dx.doi.org/10.1111/j.2044-8317.2004. tb00142.x

Hemphill, S. A., Heerde, J. A., Herrenkohl, T. I., \& Farrington, D. P. (2015). Within-individual versus between-individual predictors of antisocial behaviour: a longitudinal study of young people in Victoria, Australia. Australian \& New Zealand Journal of Criminology, 48(3), 429-445. Doi: https://doi.org/10.1177/0004865815589829

Henrysson, S. (1963). Correction of item-total correlations in item analysis. Psychometrika, 28(2), 211-218. Doi: http://dx.doi.org/10.1007/ BF02289618

Holmes, S. E., Slaughter, J. R., \& Kashani, J. (2001). Risk factors in childhood that lead to the development of conduct disorder and antisocial personality disorder. Child Psychiatry and $\mathrm{Hu}$ man Development, 31(3), 183-193. Doi: http:// dx.doi.org/10.1023/A:1026425304480

Jessor, R., \& Jessor, S. L. (1977). Problem behavior and psychosocial development: a longitudinal study of youth. San Diego, CA: Academic Press.

Jessor, R., Donovan, J. E., \& Costa, F. M. (1991). Beyond adolescence: problem behavior and young adult development. Cambridge, UK: Cambridge University Press.

Kennedy, A. P., Epstein, D. H., Phillips, K. A., \& Preston, K. L. (2013). Sex differences in cocaine/heroin users: drug-use triggers and craving in daily life. Drug and alcohol dependence, 132(1), 29-37. Doi: http://dx.doi.org/10.1016/j. drugalcdep.2012.12.025

Klingzell, I., Fanti, K. A., Colins, O. F., Frogner, L., Andershed, A. K., \& Andershed, H. (2016). Early childhood trajectories of conduct problems and callous-unemotional traits: The role of fearlessness and psychopathic personality dimensions. Child Psychiatry \& Human Development, 47(2), 236-247. Doi: https://doi. org/10.1007/s10578-015-0560-0

Knoll, L. J., Magis-Weinberg, L., Speekenbrink, M., \& Blakemore, S. J. (2015). Social influence on risk perception during adolescence. Psychological science, 26(5), 583-592. Doi: https://doi. org/10.1177/0956797615569578

Latimer, J., Kleinknecht, S., Hung, K., \& Gabor, T. (2003). The correlates of self-reported delinquency: Analysis of the national longitudinal survey of children and youth. Ottawa, $\mathrm{ON}$ : Research and Statistics Division, Department of Justice Canada. Retrieved from: http://examenequitesalariale.gc.ca/eng/rp-pr/fl-lf/famil/ rr03_yj2-rr03_jj2/rr03_yj2.pdf

Latimer, W. W., Stone, A. L., Voight, A., Winters, K. C., \& August, G. J. (2002). Gender differences in psychiatric comorbidity among adolescents with substance use disorders. Experimental and Clinical Psychopharmacology, 10(3), 310-315. Doi: http://dx.doi.org/10.1037/10641297.10.3.310

Loeber, R., \& Dishion, T. (1983). Early predictors of male delinquency: A review. Psychological Bulletin, 94(1), 69-99. Doi: http://dx.doi. org/10.1037/0033-2909.94.1.68

Loeber, R., \& Stouthamer-Loeber, M. (1998). The development of juvenile aggression and violence: Some common misconceptions and controversies. American Psychologist, 53(2), 242-259. Doi: http://dx.doi.org/10.1037/0003-066X.53.2.242

Loeber, R., Burke, J.D., Lahey, B. B., Winters, A., \& Zera, M. (2000). Oppositional defiant and 
conduct disorder: a review of the past 10 years, part I. Journal of the American Academy of Child and Adolescent Psychiatry, 39(12), 14681484. Doi: http://dx.doi.org/10.1097/00004583200012000-00007

Luengo, M. A., Carrillo, M. T., Otero-López, J. M., \& Romero, E. (1994). A short-term longitudinal study of impulsivity and antisocial behavior. Journal of Personality and Social Psychology, 66(3), 542-548. Doi: http://dx.doi. org/10.1037/0022-3514.66.3.542

Luengo, M. A., Otero-López, J. M., Romero, E., Gómez-Fraguela, J. A., \& Tavares-Filho, E. T. (1999). Análisis de ítems par ala evaluación de la conducta antisocial: un estudio transcultural. [Item analysis for assessment of antisocial behavior: A cross-cultural analysis]. Revista Iberoamericana de Diagnóstico y Evaluación Psicológica, 1, 21-36.

Maneiro, L., Gómez-Fraguela, J. A., Cutrín, O., \& Romero, E. (2017). Impulsivity traits as correlates of antisocial behaviour in adolescents. Personality and individual differences, 104, 417-422. Doi: https://doi.org/10.1016/j.paid.2016.08.045

Mirón, L., Otero-López, J. M., \& Luengo, M. A. (1988). Un estudio de la influencia de las interacciones familiares sobre los distintos tipos de conducta desviada de los adolescentes varones. [A study of the influence of the family interactions on the different types of the deviated behavior in male adolescents]. Análisis y Modificación de Conducta, 14(39), 5-23.

Morgado, A. M., \& da Luz Vale-Dias, M. (2016). Antisocial behaviour in adolescence: Understanding risk factors and mediators through a structural equations model. International Journal of Developmental and Educational Psychology, 2, 381-392. Doi: https://doi.org/10.17060/ ijodaep.2016.n2.v1.245

Mullis, R. L., Cornille, T. A., Mullis, A. K., \& Huber, J. (2004). Female juvenile offending: A review of characteristics and contexts. Journal of Child and Family Studies, 13(2), 205-218. Doi: https:// doi.org/10.1023/B:JCFS.0000015708.71295.2a

Nardi, F. L., Hauck Filho, N., \& Dell'Aglio, D. D. (2016). Predictors of antisocial behavior in adolescents. Psicologia: teoria e pesquisa, 32(1), 63-70.

Nunnally, J. C., \& Bernstein, I. (1994). Psychometric theory (3rd ed.). New York, NY: McGraw Hill.

Ogloff, J. R., Campbell, R. E., \& Shepherd, S. M. (2016). Disentangling Psychopathy from Antisocial Personality Disorder: An Australian Analysis.Journal of Forensic Psychology Practice, 16(3), 198-215. Doi: http://dx.doi.org/10. 1080/15228932.2016.1177281

Olzcak, P. V., Parcell, S. R., \& Stott, M. W. (1983). Defining delinquency: Specificity of the research sample and the right to treatment. Journal of Clinical Psychology, 39(6), 1007-1012. Doi: http://dx.doi.org/10.1002/1097-4679(198311)3 9:6<1007::AID-JCLP2270390633>3.0.CO;2-Y

Paquette, D. (2015). An Evolutionary Perspective on Antisocial Behavior: Evolution as a Foundation for Criminological Theories. In Morizot, J. \& Kazemian, L. The Development of Criminal and Antisocial Behavior (pp. 315-330). London: Springer. Doi: http://dx.doi.org/10.1007/9783-319-08720-7 20

Pelissier, B. \& Jones, N. (2005). A review of gender differences among substance abusers. Crime \& Delinquency, 51(3), 343-372. Doi: http://dx.doi. org/10.1177/0011128704270218

Pridemore, W. A. (2002). Social problems and patterns of juvenile delinquency in transitional Russia. Journal of Research in Crime and Delinquency, 39(2), 187-213. Doi: http://dx.doi. org/10.1177/002242780203900203

Quay, H. C. (1987). Patterns of delinquent behavior. In H. C. Quay (Ed.), Handbook of juvenile delinquency (pp. 118-138). New York, NY: John Wiley \& Sons

Rhee, S. H., \& Waldman, I. D. (2002). Genetic and environmental influences on antisocial behavior: a meta-analysis of twin and adoption studies. 
Psychological Bulletin, 128(3), 490-529. Doi: http://dx.doi.org/10.1037/0033-2909.128.3.490

Romero, E., Gómez-Fraguela, J. A., Luengo, M. A., \& Sobral, J. (2003). The self-control construct in the general theory of crime: an investigation in terms of personality psychology. Psychology, Crime \& Law, 9(1), 61-86. Doi: http://dx.doi. org $/ 10.1080 / 10683160308142$

Romero, E., Luengo, M. A., Sobral, J., \& Marzoa, J. A. (2001). Values and antisocial behavior among Spanish adolescents. The Journal of Genetic Psychology, 162(1), 20-40. Doi: http://dx.doi. org/10.1080/00221320109597879

Rumpold, G., Klingseis, M., Dornauer, K., Kopp, M., Doering, S., Höfer, S., Mumelter, B., \& Schüßler, G. (2006). Psychotropic substance abuse among adolescents: a structural equation model on risk and protective factors. Substance Use \& Misuse, 41(8), 1155-1169. Doi: http:// dx.doi.org/10.1080/10826080600752136

Russell, M. A., \& Odgers, C. L. (2016). Desistance and life-course persistence: findings from longitudinal studies using group-based trajectory modeling of antisocial behavior. In Goldstein, Naomi E. S. (Eds). APA handbook of psychology and juvenile justice (pp. 159-175). Washington, DC: American Psychological Association. Doi: http://dx.doi.org/10.1037/14643-008

Ryan, J. P., Williams, A. B., \& Courtney, M.E. (2013). Adolescent Neglect, Juvenile Delinquency and the Risk of Recidivism. Journal of Youth Adolescence, 42(3), 454-465. Doi: http://dx.doi. org/10.1007/s10964-013-9906-8

Sehn, A., Porta, D., Santos, S., \& Dias, A. C. (2016). Risk factors in the life of Portuguese adolescents in conflict with the law. Estudos e Pesquisas em Psicologia, 16(2), 568-589.

Seisdedos, N. (1988). Cuestionario A-D de conductas antisociales y delictivas. [A-D Antisocial and delictive behaviours questionnaire]. Madrid, ES: TEA.

Sherman, S. J., Chassin, L., Sherman, J. W., Presson, C. C. \& Macy, J. T. (2016). Social psycholo- gical factors in adolescent and adult smoking: Findings and conclusions from a 30-year longitudinal study. UC Davis: 1605864.

Storvoll, E., Wichstrom, L., Kolstad, A., \& Pape, H. (2002). Structure of conduct problems in adolescence. Scandinavian Journal of Psychology, 43(1), 81-91. Doi: http://dx.doi.org/ 10.1111/1467-9450.00271

Styles, R. (2015). How words and speech influence covert and overt behaviour: A functional self-discrimination measure of verbal behaviour (doctor's thesis). Australian National University, Camberra, Australia.

Svensson, R. (2003). Gender differences in adolescent drug use: The impact of parental monitoring and peer deviance. Youth \& Society, 34(3), 300-329. Doi: http://dx.doi.org/10.1177/0044118X02250095

Tabachnick, B. G., \& Fidell, L. S. (2007). Using multivariate analysis. Boston, MA: Allyn \& Bacon/Pearson Education.

Thornberry, T. P., \& Krohn, M. D. (2000). The self-report method for measuring delinquency and crime. In D. Dufee, R. D. Crutchfield, S. Mastrofski, L. Mazerolle, \& D. McDowall (Eds.), Measurement and analysis of crime and justice, Vol. 4. Criminal justice 2000 (pp. 33-83). Washington, DC: National Institute of Justice. Thornberry, T. P., Huizinga D., \& Loeber R. (2004). The causes and correlates studies: Findings and policy implications. Juvenile Justice, 9(1), 3-19. Retrieved from: https://www.ncjrs.gov/ html/ojjdp/203555/jj2.html

Tuvblad, C., Eley, T. C., \& Lichtenstein, P. (2005). The development of antisocial behavior from childhood to adolescence: A longitudinal twin study. European Child and Adolescent Psychiatry, 14(4), 216-225. Doi: http://dx.doi. org/10.1007/s00787-005-0458-7

van Lier, P. A. C., Vitaro, F., Wanner, B., Vuijk, P., \& Crijnen, A. A. M. (2005). Gender differences in developmental links among antisocial behavior, friends' antisocial behavior, and peer rejection 
in childhood: Results from two cultures. Child Development, 76(4), 841-855. Doi: http://dx. doi.org/10.1111/j.1467-8624.2005.00881.x

van Lier, P. A. C., Wanner, B., \& Vitaro, F. (2007). Onset of antisocial behavior, affiliation with deviant friends, and childhood maladjustment: a test of the childhood and adolescent-onset models. Development and Psychopathology, 19(1), 167-185. Doi: http://dx.doi.org/10.1017/ S0954579407070095

White, S. F., Tyler, P. M., Erway, A. K., Botkin, M. L., Kolli, V., Meffert, H., Pope, K. \& Blair, J. R. (2016). Dysfunctional representation of expected value is associated with reinforcement-based decision-making deficits in adolescents with conduct problems. Journal of Child Psychology and Psychiatry, 57(8), 938-946. Doi: http:// dx.doi.org/10.1111/jcpp.12557

World Health Organization (1992). The ICD-10 classification of mental and behavioural disorders: Clinical description and diagnostic guide lines. Geneva, Switzerland: Author.

Youngs, D., Canter, D., \& Cooper, J. (2004). The facets of criminality: A cross-modal and cross-gender validation. Behaviormetrika, 31(2), 99-111. Retrieved from: https://www. jstage.jst.go.jp/article/bhmk/31/2/31_2_99/_pdf
Received: August 23, 2016

Approved: July 24 ${ }^{\text {th }}, 2018$ 
